\title{
THE BALKAN ROAD AND THE GUARDING OF EUROPE: THE REFUGEE CRISIS ON THE BORDERS OF SLOVENIA
}

\author{
Ksenija VIDMAR HORVAT
}

COBISS 1.01

\section{ABSTRACT}

The Balkan Road and the Guarding of Europe: The Refugee Crisis on the Borders of Slovenia The article investigates public reactions to the refugee crisis in the autumn of 2015. The focus is on the emerging "post-Schengen" imaginaries of the border which are formed in reaction to the actions by the member states at the periphery (Hungary, Croatia) and in the centre's alleged expectations that the external borders of the $\mathrm{EU}$ will be protected. In this constellation, Slovenia assumes the role of the border guard of Europe, which is based on the memories of the 20th century, in particular of the ascribed traumatic legacy of being part of the socialist bloc. The theoretical argument derived from the study emphasises the importance of historical treatments of public perceptions about political community, borders and solidarity, as well as the need for localized analyses of popular beliefs of belonging which stem from the regional histories.

KEY WORDS: refugees, the Balkan road, borders, strangers, Slovenia, precariousness

\section{IZVLEČEK}

Balkanska pot in varuhi Evrope: begunska kriza na mejah Slovenije

Članek obravnava javne odzive na begunsko krizo jeseni 2015. Temeljno izhodišče analize so vznikajoči "post-schengenski« imaginariji meje, ki se oblikujejo v odzivih na ukrepe držav članic EU v periferni soseščini in glede na pričakovanja centra o varovanju zunanjih meja. Slovenija v tej konstelaciji, ki se opira na spomine na 20. stoletje, predvsem na pripisano dediščino travmatičnega pripadanja socialističnemu bloku, zavzema mesto varuha meje. Iz te analize izpeljani teoretski argument poudari pomen zgodovinske obravnave javnih predstav o politični skupnosti, mejah in solidarnosti ter lokaliziranih študij popularnih predstav o pripadnosti, ki izhajajo iz regijskih zgodovin.

KLJUČNE BESEDE: begunci, balkanska pot, meje, tujci, Slovenija, prekarnost

PhD in Sociology of Culture; University of Ljubljana, Faculty of Arts, Aškerčeva 2, SI-1000 Ljubljana; ksenija.vidmar@ff.uni-lj.si 


\section{INTRODUCTION: THE TIME OF BORDERS}

Today's world is a world of borders. As many scholars have argued (Andersson 2014; Balibar 2003; Carr 2015; Walters 2006), the perception that our time is defined by the freedom of movement and that globalization has induced the collapse of the borders is a highly overrated myth. In fact, we are faced with a new border situation, based on the multiplication of borders as well as technological advancement and sophistication beyond imagination (Carr 2015). These include satellite monitoring, remote control and mobile borders as concerns technology, proliferation of professional profiles as concerns border agents, and a plethora of formal, informal and private institutions of control (Bučar Ručman 2016) in between. In Europe alone, the monitoring of borders involves national governments, police forces and immigration offices as well as FRONTEX, RABIT (The Rapid Border Intervention Team), PJC (Police and Judicial Cooperation in Criminal Matters), Europol and Eurojust (Carr 2015: 23), to name but a few. By means of ghettoization and the concept of gated communities, borders are expanding within the cities (Balibar 2003; Bauman 2011), through zip files and other security passwords crossing the walls of buildings, communication networks and personal data (dataveillance, Bučar Ručman 2016). In geopolitical terms, the extra-territorialization of juridical powers on the borders has already been established, in places like the Spanish autonomous cities of Ceuta and Melilla in North Africa. While they are imposing new barriers to movement, borders have also turned into a profitable business. ${ }^{1}$ Trading in "illegalities" (Carr 2015) and "clandestine migration" (Andersson 2014) includes private companies but also governments, research institutes and aid organizations (Andersson 2014: 14). In brief, in the de-territorialized globe of the $21^{\text {st }}$ century, borders present a vast and expanding terrain of control, centring around the uneven distribution of mobility (Andersson 2014: 7) on the one hand and the classification of privileges and crimes of movement (Melossi 2003) on the other.

In critical accounts, borders appear to be part of a large geo-technological apparatus existing in a semi-secretive sphere of agencies, units, centres and investigation rooms, governed by self-serving protocols and rules, and bound into a system which to a large extent is undetectable to the general public on whose behalf it allegedly operates. With the exception of anthropological investigations of the people turned migrants (cf. Andersson 2014), and ethnographic accounts of life in border regions (Wastl Walter et al. 2004), in social writing, the current high-tech border regimes seem to have acquired a quality of existing outside (human) time and space. However, the current refugee crisis in the EU has uncovered a new border reality, one which has collapsed "back" into the past. In addition to re-instituting some of the types of border controls removed in 2007 by the Schengen Agreement, we are witnessing the emergence of a post-Schengen European map, one heavily sequestered across the lines of modern nationalism and at the same time clustered around new, and until recently, unlikely border allies, such as Orban's Hungary, Merkel's Germany and Erdogan's Turkey. The cartography of European borders since the onset of

1 In addition to private enterprises paid to develop operations such as Mariss, Limes, and Dolphin, all targeting illegal immigration, firms profiting from investments in "migration management" with public money also include Airbus, the arms manufacturer Finmeccanica and the security company Thales. Since 2000, 226 million euros have be116en spent on border control equipment such as boats, drones, Dorados, and night glasses; an additional 16 million euros was paid to programs searching for methods to replace sniffer dogs, Delo (9. 11. 2015: 25). 
the crisis has furthermore collapsed into new historical divisions, defined by the roads to Europe taken by migrants from the global South. In the Mediterranean area, the main path of entry, known to the European public since at least 2000, revolves around the socalled "Mediterranean road". ${ }^{2}$ Taken mainly by refugees from Africa, it bears the imprint of European (post)colonial violence. In the South-East, the "Balkan road" momentarily appeared in 2015-2016. Cutting across the territories of the post-socialist states, it is overwritten with the script of the (post)Cold War narrative.

The theoretical concern of this article is how to (re)locate history in the field of border studies. The argument develops in three stages. First, the postnational state as the new historical reality of border control is explicated: this is done through a brief analysis of the historical contradictions emerging from the evolution of the modern state from the national to the postnational rule of governmentality and the arrival of the "neoliberal subject". The thesis is that the neoliberal "precariousness" demands that borders are treated theoretically as both sites of the fear of migration in space (kinophobia) and the fear of passing of social time (chronophobia). The central part of the analysis connects public perceptions of time and history in relation to borders on the case of Slovenia. Using the method of discourse reading of a case sample of media reports about the refugee crisis in the autumn of 2015, I show how history and memory of the "Wall" are facilitated by local media and politicians to legitimize the nation's role as the border guard of Europe. In conclusion, I summarize the findings by underlining the need to theoretically link studies of global migration with regional histories, using public memory as an important mediator in the settling of issues of postnational community, solidarity and action.

\section{THE CENTURY OF MIGRATION}

Migration is a key feature of contemporary societies. Whereas movement is a transhistorical fact of human history, we are currently witnessing a drastic shift in scaling. "The past two decades have seen a sharp growth in the number of people, enterprises, and places expelled from the core social and economic orders of our time" (Sassen 2014: 1). At the present over 1 billion people globally are displaced (Nail 2016). In the EU, a total of 3.8 million people immigrated to one of the EU 28 Member States during 2014, while at least 2.8 million emigrants were reported to have left an EU Member State; 12.4 thousand people are "stateless". ${ }^{3}$ Climate change, land grabbing (coupled with the 'foreignization' of farmlands and the 'financialization' of food commodities, Baird and le Billon 2012) and wars are the contributing factors to the expulsion of people in the global South. The 2008 financial crisis has underwritten the displacement of millions of people worldwide, including in the global North ( 9 million in the US). Globally, the predictions are that migration rates will continue to grow over the next twenty-five years. "The twenty-first century will be the

2 According to Frontex, the primary migratory routes to Europe are: the Western African route, Western Mediterranean route, Central Mediterranean route, Apulia and Calabria route, Circular route from Albania to Greece, Western Balkan route, Eastern Mediterranean route, and Eastern Borders route; frontex.europa.eu/trends-and-routes/migratory-routes-map, accessed (21. 9. 2016).

3 http://ec.europa.eu/eurostat/statistics-explained/index.php/Migration_and_migrant_population_statistics (15. 9. 2016). 
century of the migrant," Thomas Nail writes (2016), while people who migrate, either by choice or by force, will constitute the dominant figure of the changing, postnational world.

The management of migration is becoming a leading challenge for the social (re) organization of the postnational state as a whole. The epochal transformation we call globalization, Sassen writes, "is taking place inside the national to a far larger extent than is usually recognized" (Sassen 2014: 1). Migration stands at the core of this transformation. (This, as will be explained further down, should by no means be confused with migration hysteria based on amplification of numbers and the scope of the alleged "threats" to the host societies.) So far, not much political concern (beyond the usual rhetoric of "migration as an opportunity") 4 has been displayed. Moreover, despite the fact that the late twentieth-century policies of integration, assimilation or multicultural cohabitation have in many ways already proven to be inadequate in addressing issues of belonging and membership, have been politically discredited and will continue to wither in both their public appeal and actual efficiency (Kymlicka 2015), no serious attempts to develop new agendas of social and political organization of life can be detected. To the contrary, the withering of state powers to manage their populations has turned backwards to modern tools of control through bordering (Brown 2010) on the geo-graphic side, and to the furthering of the modern individualization process in its neoliberal edition on the body-graphic side. The combined effect is that rather than creating conditions for minimizing the impacts of globalization, the postnational state has added to the confusion, anxiety and conflict.

Two related issues can be listed among the many causes of this historical impasse. First, there is a growing confusion of clear boundaries between citizens and immigrants, outsiders and insiders (Calavita 2005: 13-14). A process which Newman describes as "societal compartmentalization" (Newman 2006: 175) contributes to the blurring of the boundaries between the "domestic" and the foreign populace at the multiple levels of neighbourhoods, cities, regions, states and continents. Considering the scope of the transnationalization of societies, it may even be unproductive to use the term "integration", as it is no longer clear what (or which group) constitutes the measure (of integration) and who is to be integrated into where and what. The massive spread of human movement has reshaped social territories and cultural identities of local and transnational communities to the degree where the modern politics of citizenship is increasingly losing ground as the dominant principle of governmentality. This includes the shaking of the social and cultural embeddedness of identity (Squires 2002: 229), as well as firm classifications of national belonging (Soysal 2002).

Second, both the sovereignty and the legitimacy of the modern state are at stake. Notwithstanding that, as Sassen writes, "[t]erritory, law, economy, security, authority, and membership all have largely been constructed as national in most of the world, albeit rarely with the degree of autonomy posited in national law and international treaties" (Sassen 2014: 49), the waning power of the state is perceived as a major historical crisis. As Sassen also argues, the sovereignty of the state has always been a fiction to a certain degree (ibid.), but this should not prevent us from taking seriously various recent developments in search of the re-institution of that fiction, most significantly through the inventions of new, post-Westphalian types and technologies of state bordering and surveillance. The

4 Cf. also UN, 2015 European Agenda on Migration, http://ec.europa.eu/dgs/home-affairs/whatwe-do/policies/european-agenda-migration/index_en.htm. 
global neoliberal economy has corroded the elegance of the modern divide between the inside and the outside of the nation (Brown 2010: 25): forces of globalization nowadays materialize inside the countries (Sassen 2014: 5) as much as they operate transnationally. Deregulation of national borders, a prime concern of the previous decade, should therefore be studied in pair with international and internal, intra-national compartmentalization across socio-economic and juridical spaces.

\section{NEOLIBERAL BORDER POLITICS}

In contrast to the modern perception according to which borders were there to protect and unify territorial integrity and the communal sense of the cultural self, today, borders are moving inwards, where they participate in the management of the post-national biopolitics of belonging and membership. Most evident is the shift in the relationship between state and society (Rumford 2006: 159). In modern history, the key assumptions of governing by borders were the stasis of the (social and territorial) space (Newman 2006: 175), and that borders were an outcome of a political (either violent or peaceful) decision-making process (ibid.). As concerns the management of population, modern rationality differentiated between 'bare life' (zoe) and political life (bios), or rather, as Agamben (2004) argues, the whole point of citizenship discourse (the contract) was to obliterate the fact of its embeddedness in bare, biological life. The contract was extended into the post-WWII world order through the human rights/citizenship rights divide, which transposed the national principle onto the management of human life and global humanity (ibid.). In the $21^{\text {st }}$ century, the structure of the contract is transforming towards the precarization of life (Butler 2004).

As Bauman (2016) argues, this is a new stage of individualization. Neoliberal rationality encourages individuals to transform their selves into projects to be managed by the rule of commercial entrepreneurship, wherein there is not much room for interpersonal solidarity and empathy (McCormack, Salmenniemi 2016). The precarity of the existential condition (Bauman 2016) should not be confused with the decline of the social tout court, however. In the post-welfare societies, bonds of belonging are still very much patterned by the historical experience of solidarities based on ethno-cultural belongings. Regardless of the fact that it is the state which has been seen responsible for the "destabilization of the conduct of life" (Bauman 2016: 59), state thinking is still determining the perception of safety. Although "no longer promising protection and security" (ibid.), the state is invoked when defending social rights and political entitlements. No matter how vague the sense of belonging to the nation-state, the rights of citizenship, as defined by modern rationality, still governs people's expectations and claims (to privilege).

In other words, whereas the state has lost much of its power over the borders, and has, in its subsidiary role, paired with agents of global neoliberalism in order to multiply, fortify and expand internal borders among groups of state-affiliated as well as state-less people (in a way thus itself becoming an agent of the liquefying of the social), national borders of citizenship still play a vital role in public definitions of rights and solidarity. While in the 1990s some could still argue that national citizenship was losing ground to a more universal model of membership, anchored in deterritorialized notions of "persons' rights" (Soysal 1994: 3), the present-day reality is closer to the new "walling" of citizens against "strangers". The current condition of the post-welfare state thus has underlined, instead of 
undermined, claims to citizenship. The neoliberal release of the modern grip of the borders has intensified the fear of others while further relieving the state, and agents who profit from migrant labour, of their implication in the "crime" of the borders (Melossi 2003).

\section{THE PRECARIOUS BODY}

Borders are spectacular sites on which the global(ized) precariousness of human existential conditions is transferred onto the back of the other. Ideological nuances inscribed in either the "polite" or the far-right extremist articulations notwithstanding, at the crossing stations of the impoverished Western social economies, the migrant becomes the source of our own insecurity and is deemed an agent of inequality (Nicholson et al. 2016: 337).

As seen above, the modern state border operated primarily reactively. Drawing an administrative, political and military defence line, its main "task" was to keep the human enclaves within as intact as possible. Stability was further provided by manufacturing bonds of solidarity based on ethno-cultural or civic principles, whereas deviations from conditions of belonging enforced by nationalist patriotism were deemed treason. Individual critical patriots could found themselves in exile, but, through acts of denaturalization, large groups of people could also be expelled. Thus, the modern border operated primarily within, acting as a tool of surveillance and control for the maintenance of the civic loyalties of citizens living inside its operative circle (Balibar 2003).

The postnational border operates primarily pro-actively, or as Andersson (2014: 7) argues, productively: sorting out among humans in line to pass, legally or illegally, the crossing points, it is the site of the production of subjects qua nationals and others. The border filters people on the move, in effect turning some of them into a legal category of immigrants while letting others pass by unnoticed. In light of the dramatic decomposing of state institutions of civic certainty and nationhood stability, borders are among the last resorts of the validation of national belonging for people with national passports. For those without papers, the "sans papiers", they are the entry point of becoming - as a migrant, a refugee, an asylum seeker - the other.

The migrant's precariousness is caught in the circularity between eternal waste (Pajnik 2016) and recruitment of labour. In contrast to the precariousness of sedentary labour, however, the migrant's condition of circularity (i.e. precariousness) entails both economic and juridical status. Economically, precariousness in the case of migrant workers depends on the kind of jobs they are deemed suitable for, the three Ds (dirty, dangerous, demanding, Pajnik 2016). These are mainly short-term, insecure, irregular jobs, based on temporary permits, dependent on the duration of the projects, subcontracting, seasonal work in agriculture, etc. (ibid.); in the case of feminized migrant labour, tending to the needs of the host country's households, temporality is defined by the life cycles of death (of the elderly in care) and growing up (children going to school) (Mezzadra, Neilson 2013). Juridically, immigration laws ensure the durability of precariousness through criminalization and (racial) difference (Calavita 2005). This implies the containment in non-citizenship and/or illegality: "The very qualities that make a group suitable for recruitment as 'labour' demonstrate its lack of qualities for membership” (Solberg, in Calavita 2005: 12). The latter can be illustrated by the recruitment of Mexican migrants at the US/Mexico border, where forces of neoliberalism "work together to create a criminal population without 
labour rights (expulsion) in order to redistribute them as surplus labour power according to the needs of US valorization (expansion) (Nail 2016: 222).

The border, operating as the factory of migrant precariousness, is, to the people living within the borders as "natives", mainly invisible in this capacity; yet - through the media and public performances of national populists - they can sense its presence, casting the end-product, the border subject, as a potential threat to the tranquillity of the lives within.

\section{KINO- AND CHRONOPHOBIA}

The diagnosis of why this politics of fear works so effectively within populations that are free of concerns of legal status has become almost unanimous in its judgment in recent years. Whereas the usual line of explanation follows the historical progression of fear of strangers from the outskirts of the constitution of the modern community, as explained in sociology by Simmel and Schutz (Marrota 2010), the present-day verdict seems to be that it is the common fate of precariousness of life of both the natives and the immigrants which has led to the latter being deemed the culprit in the destruction of the existential order. In this context, Bauman, by reiterating Aesop's fable of the hares and the frogs, calls the migrants bearers of bad news: "Those nomads - not by choice but by the verdict of a heartless fate - remind us, irritatingly, infuriatingly and horrifyingly, of the incurable vulnerability of our own position and of the endemic fragility of our hard won well-being" (Bauman 2016: 16).

Kinophobia (Nail 2016), ${ }^{5}$ the fear of people dislocated in space (territorial, social, or economic), works in pair with fears in time, or better yet, of time. Following Nail (ibid.), this type of fear could be described as chronophobia. This includes the migrant's own change of time perspective concerning their personal biography and expressed in different forms and states of social vulnerability, as well as the time consciousness of the host community. As indicated by the rising nationalism in Eastern Europe (Forrester et al 2004), the time perspective, borne on the invocation of historical entitlements and the 'anterior presence' discourse, ${ }^{6}$ is an important aspect of argumentation for the anti-immigration stance. Since the 2008 economic crisis, the relationship between migration and time management has gained additional curves across Europe. In the Mediterranean, for instance, a new "regional time" is emerging (Knight, Stewart 2016). As reported by ethnographers of austerity, it oscillates between memories of past securities and the "eternal" present, threatening to irrevocably destroy the planning of future (Bryant 2016). As already argued above in the case of postnational claim to the privileges of national citizenship, confusion

5 Nail speaks of kinopolitics to define the motion of migrant labour. At the border this politics operates in three cycles, or circuits: the border circuit which works by deportation; the detention circuit which extracts mobility by incarceration or settlement in camps; and the labour circuit which can lead to either labour recruitment or deportation (Nail 2016: 31-32)

6 The 'we were here first' discourse, as Eugen Roosens warns, is a dangerous weapon because it appears as 'common sense'. 'This type of argumentation', Roosens contends, 'has become in political power relations and also in the media a tacit compromise much more "acceptable" [or "politically correct"] than blunt xenophobia or aggressive racism' (Roosens, quoted in Shippers 2007: 105). 
of the time perspective, encompassing "simultaneous pasts and presents" (Knight, Stewart 2016: 5) plays a role in the structuring of social experience and expectations of the service of the (postnational) state. It is not hard to see fertile soil for welfare chauvinism piling up on the abandoned fields of the social state, which may be soon assisting the extreme right in directing the public fears of migrants. Precarity has already proven to be effective in providing the conditions for confusing economic vulnerability with the migrant "threat". Or, as Robinson puts it, "(e)conomic globalization denationalizes national economies and in contrast immigration renationalizes politics" (2009: 23; for the Slovenian case, see Bučar Ručman, Kanduč 2016). In the post-crisis reconstitution, as will become evident below, memories of national borders become vital agents in the negotiation of the safeguarding of the national welfare.

\section{THE BALKAN ROAD}

What follows is a discourse summary of newspaper coverage of the "Balkan road" in the leading national daily Delo. The analysis focuses on three topics: the Balkan refugee road itself, the "security theme"; and the image of the "razor-wire fence".

\section{The Balkan road}

Across Central and Eastern Europe, the experience of the Berlin Wall, regardless of its actual geographic and political presence, has constituted a key emotion of post-socialist integration into the EU. After the revolutions of 1989, the region as a whole was marked by discourses of "catching up", "defrosting", "return to history" (Forrester et al. 2004); in this teleological narrative, (Western) Europe appeared as a final destination in both political and cultural development. In Slovenia, however, a special effort was invested to be disassociated with the region, claiming a Central European heritage as the historical proof of the commensurability of Slovene identity with European history. When accepted into the Schengen space, newspaper headlines such as "Border renaissance of Central Europe", "Triumph of freedom" and "Confirmation of Europeanness" (Vidmar Horvat 2009) continued the process of "ethnic engineering" (Štiks 2010). The so-called debalkanization process of the 1990s (Petrović 2009; Velikonja 2005) coupled with the self-ascribed cordon sanitaire role during the violent break-up of Yugoslavia (Mihelj 2004) patterned the master narrative of accession to the EU in 2004 and of inclusion among the Schengen states in 2007.

The opening of the "Balkan refugee road" invoked Orientalist cultural images of the region. However, two discursive strategies appear in the reports, neither directly associated with the customary notion of the Balkans as the European "other". Rather, the image of the oriental Balkan was mobilized to point to Brussels on the one side and to Turkey on the other side of the European management of the refugee crisis. Headlines and sub-headlines such as "Eastern bazaar at the Brussels table" (28. 11. 2015), "Brussels Bazaar" (17. 10. 2015), "Turkey is becoming the master of the Balkan road" (ibid.), and "More Order at the Balkan Corridor of Chaos" (26. 10. 2015) indicated a novel imagery of Europe in which Turkey appeared as both a (political) partner and a (cultural) colonizer. "Brussels", on the 
other hand, entered the "dark continent" (Todorova 2001), demonstrating a similarity to its handling of the Balkan crisis in its incapacity to mitigate humanitarian solutions to the political conflict (a supressed memory of the war in Bosnia), and in a subservient role to the Oriental "empire". The confusion of history, culture and geography provided a map of the region in which Slovenia moved from the place of a peripheral Member State to the role of a Schengen centre. Above all, a critical distance from the centre, paradoxically, fuelled a potent fantasy by which the regional map would, yet once more in history, show Slovenia as a non-Balkan destination.

\section{Security}

The image of Slovenia as the border guard emerged in late October and intensified in November 2015. If in August of the same year, EU Member States, including Slovenia, expressed both objection and abjection in response to Orban's announcement of his plan to fence in the country, in a matter of a few weeks, news about the Slovene government's purchase of the razor-wire fence was starting to appear. At first, the prime minister and the government (centre-left) coalition remained secretive about the plan, but already by the end of October, ideas about setting up "technical barriers" (4. 11. 2015) were communicated to the public. In September, Orban was called "the executor of European dirty business" (24. 9. 2015); by mid-October, the prime minister confirmed that getting closer to Hungary's way of dealing with the issue could be an option (24. 10. 2015).

Security was a key legitimation topic. The discourse on security was given a featured role on the occasion of the implementation of the Schengen border in former Eastern Europe in 2007; back then, its main discursive companion was "our" freedom (Vidmar Horvat 2009). Since then, securitization has become a partner product of the debordering of Europe as a whole. Anxious reactions to the reports about a club of selected countries debating the introduction of a mini-Schengen after the Paris terrorist attacks triggered an especially strong flow of "worthy border guard" claims. Slovenia has justified the trust, has proven an effective and reliable "guard of the Schengen border", were some of the statements from the Minister of the Interior. The same minister also pointed to what was in her view the real problem, namely that an "unsorted" flow of refugees comes to Slovenia, where economic migrants mix with the refugees (10.11. 2015).

The time-operation of the border is an integral aspect in the management of fear. Already in 2007, when Slovenia was to become the guard of the external Schengen border, in Croatia, newspapers wrote of the return of the "iron curtain" to the region. On the other side, fears erupted of the pre-Schengen border returning to their lives (which in fact happened twice, in the northern region during the European Cup in Austria and the G8 meeting in Trieste, Italy in 2009). In addition, media reports were filled with evidence of humiliation, travelling as cultural judgments across the lifted administrative borders in the North and West. In defence, the acceptance into the Schengen area was presented as a token of cultural worthiness and, relatedly, that this worthiness implied taking on the role of the border guard (Vidmar Horvat 2009).

In the new, 2015 constellation of rebordering of Europe, fears of being caught within the iron curtains of the new epoch were being mediated through the combined invocation of the security measures and the racialization of the border. As concerns the former, assuming 
the role of the guardian of both its own national territory and the European empire as a whole created an image of centrality in terms of management of the crisis. With its own push to administer the "Balkan road", this peripheral state could not be ignored. As concerns the latter, claiming the power to differentiate among categories of humans contested the privilege to "sort" people, a customary property of the centre. Either way, posing as a Schengen sovereign constituted a spatial and temporal advance, a moment of historical and geographic progress.

\section{THE SCHENGEN (E)MOTIONS AND THE WALL}

As Bauman notes, "securitization" is an empty discourse which, as a neologism, empowers political elites to legitimize their actions of control and frees ordinary people of the moral burden of "the fate of the wretched" (Bauman 2016: 35). In Slovenia, a Schengen border state, however, memories of past borders played a role in public attitudes and in articulating border discourse when encountering the refugees.

\section{The razor-wire fence}

While the military units were erecting the fences at a speed of 150 metres per hour (12. 11. 2015), manipulation of the numbers of refugees approaching Slovenia ${ }^{7}$ as well as fears of "backflows" from Austria and Germany (12.11. 2015) turned public attention into migration hysteria. Already an available tool within the Schengen border industry, hysteric anticipation of flows and floods of people invading the lands and homes of the peaceful Western world was used to expedite the legitimation process at home and in the region, while attaching itself to the image of the nation victimized by hordes of migrants. ${ }^{8}$ However, in Delo, the memory of the wire interfered with the legitimation processes. In a letter entitled "Concentration camp Slovenia", a reader wrote: "It is sad to see that we are using the same methods as were used during the war by the aggressor." In December, public protests against the army and fences at the borders were launched in different parts of Slovenia (11. 12. 2015); in a report from the border region of Istria, the daily used a quote from the protest as the front-page headline: "This is incomparable even to the war times" (12. 12. 2015), and reiterated peoples' protests about the "sad, terrifying scene" reminiscent of the last war (15. 12. 2015). Istrian mayors from the Slovene and Croatian sides issued a joint statement demanding the removal of the fence (17. 12. 2015), while references to the fenced-in areas of Slovenia during WWII illustrated commentaries such as "A fenced-in mind" (7. 12.: 27), "Primorje region also fenced" (11. 12.: 11), "Closing of the borders at the Balkans will revive painful memories" (26. 9.: 3), "Again Europe with iron curtain" (22. 9., 2), "refugee holocaust" (7. 9.: 5), "I hope that they do not erect a concrete Berlin Wall again (31. 12.: 4).

7 Journalists following the refugees on the Balkan road reported 10-12 thousand people on the move; the number was inflated to 30,000 by the Minister of Foreign Affairs (Delo, 11. 11. 2016).

8 As Carr (2016: 23) has argued, the "invasion" anticipated by playing with numbers has never occurred in real life; as concerns migrants from Africa, the main burden of the expulsions is split among the neighbouring countries, while only a minor portion arrives at the frontiers of the EU. 
Although small in size, the selection of reactions in Delo to the razor-wire fencing of Slovenia's eastern and southern borders nonetheless confirms that the border exists in territorial as well as time-historical social registers. Despite being recognized as "one gigantic apparatus of control", the Schengen border operates in local variations, imbued with border and other memories of the past. The traumatic experiences of WWII and Slovenia's assignment to the Eastern bloc during the Cold War created a memorial basis in the post-socialist regions on which present-day encounters with traumas and crises are lodged. Memories of past terrors of different types of fencing-in of people and states also direct the perception of the Schengen border and its exclusionary role in defining the non-Schengen people.

\section{CONCLUSION}

The passing through the turbulent present is turning borders into much more visible markers of historical place as well as time. Crises, Knight and Stewart write in relation to the 2008 global fiscal crisis, defeat routine and structure and, in their capacity to disrupt the flow of history, function as events. In terms of phenomenological description, events are cuts into the flow of time. By disrupting the routines of time passing, they acquire a "semantic density" by which they help in the historization of the present (which, under ordinary circumstances, remains unpresentable in its historicity (ibid.)). Historization occurs in relation to the past, painted through either nostalgic or traumatized memories of "how things once were". As mentioned above, for the people in Southern Europe, the crisis was such an event which evoked the memory of the social state and the moral contract of the pre-crisis debt economy. Across Europe, the 2015 refugee crisis triggered a different, border history, split along the memory lines of the debordering of the inner space and the "securitization" of the borders along the outside edge.

What, then, is a theoretical relevance of studying the Balkan road? Our research shows that the local fate of global migrants depends on regional histories, whereby public memory is an important mediator in the settling of issues of postnational community, solidarity and action. Moreover, global issues such as border control, securitization, legal and illegal migrants acquire local meanings which stem from national histories and narratives of the past, and participate in the negotiation of the identities of host communities. Whereas a country's geopolitical power is a factor in the scope of its contribution to the international "management of migration" (Čebron, Zorn 2016), the reverse is also true: peripherally enforced rules of migration control can intervene into a larger geopolitical context of transnational alignments, unsettling the hegemonic order of the centres. The EU humanitarian crisis, as regards the refugees on the Balkan road, and in front of the razor wire erected by peripheral Member States, is a good case at hand.

In his call to revive the value of human life, and acknowledge dignity as a basic humanist legacy in the European thought, Habermas notes the following:

In contrast to the territorial form of the nation-state, "globalization" conjures up images of overflowing rivers, washing away all the frontier checkpoints and controls, and ultimately the bulwark of the nation itself. The new relevance of "flow volumes" also signals how the locus of control has shifted from space to time: as "masters of speed" come to replace "rulers of territory", the nation-state appears to steadily lose its power. (Habermas 2012: 67) 
Public depictions of the "Balkan road" suggest that the time component concerns not only the technologies of control, but also invokes mental cartographies that allow for the management of the "flows" of strangers. In other words, borders and the strangers who cross them to "come to us" evolve in territories that are populated with time maps and landscapes of public memories, running in accord but also in tension with the governance of the present. Castells argues that "building blocks from history, geography, biology, productive and reproductive institutions, collective memory and personal phantasies, power apparati and religious convictions" can be employed when new social territories are being drafted (Castells 1997, quoted in Jensen, Richardson 2004: 46). The enlargement of the Schengen territories contributed a historically monumental event which in the minor territories of central Europe, such as Slovenia, triggered the evolution of mental geographies in which the "borderless" EU was very much defined by the remembering of the Europe of past borders.

While the "renaissance" of Central Europe was the officially sponsored attitude, in 2007 only a few voices warned of the implied post-imperial thinking, both emptied of memories of multicultural and multi-ethnic cohabitation and amplified in the nationalist projection of future history. This legacy today is entwined in the fences on the southern and northern borders of the Slovenian state, and defines the public response, either in its political or humanitarian version, to the suffering image of the "stranger at our door".

\section{REFERENCES}

Agamben, Giorgio (2004). Homo Sacer. Ljubljana: Koda.

Andersson, Ruben (2014). Illegality, Inc.: Clandestine Migration and the Business of Bordering Europe. Los Angeles, Berkeley: University of California Press.

Balibar, Ėtienne (2003). We, the People of Europe? Reflections on Transnational Citizenship. Princeton University Press.

Baird, Ian G., Le Billon, Phillippe (2012). Landscapes of Political Memories: War Legacies and Land Negotiations in Laos. Political Geography 31, 290-300.

Bauman, Zygmunt (2011). Collateral Damage: Social Inequalities in a Global Age. Cambridge: Polity Press.

Bauman, Zygmunt (2016). Strangers at our doors. Cambridge: Polity.

Brown, Wendy (2010). Walled States, Waning Sovereignty. New York: Zone Books.

Bryant, Rebecca (2016). On Critical Times: Return, Repetition and the Uncanny Present. History and Anthropology 27/1, 19-31.

Bučar Ručman, Aleš (2016). Družbeno nadzorstvo in mednarodne migracije: Analiza nadzorstva od globalne do lokalne poti. Dve domovini / Two Homelands 43: 11-22.

Butler, Judith (2004). Precarious Life: The Power of Mourning and Violence. London: Verso. Calavita, Kitty (2005). Immigrants at the Margins: Law, Race and Exclusion in Southern Europe. Cambridge: Cambridge University Press.

Carr, Matthew (2015). Fortress Europe: Inside the War Against Immigration. London: C. Hurst \& Co. Publishers.

Forrester, Sibelan, Zaborowska, Magdalena J., Gapova, Elena (eds.) (2004). Over the Wall/ After the Fall: Post-Communist Cultures Through and East-West Gaze. Bloomington, Indianapolis: Indiana University Press. 
Habermas, Jürgen (2012). The Crisis of the European Union: A Response. Cambridge: Polity. Jensen, Ole B., Richardson, Tim (2004). Making European Space: Mobility, Power and Territorial Identity. London: Routledge.

Kanduč, Zoran, Bučar Ručman, Aleš (2016). Razredna vojna, delo in migracije: Primer delavcev migrantov v Sloveniji. Dve domovini / Two Homelands 43: 77-89.

Knight, Daniel, Stuart, Charles (2016). Ethnographies of Austerity: Temporality, Crisis and Affect in Southern Europe. History and Anthropology 27/1, 1-18.

Kymlicka, Will (2015). Solidarity in Diverse Societies: Beyond Neoliberal Multiculturalism and Welfare Chauvinism. Comparative Migration Studies 3/17, DOI 10.1186/s40878015-0017-4.

Lipovec Čebron, Urška, Zorn, Jelka (2016). Avtonomija in nadzor migracij v evropskih »tamponskih conah«. Dve domovini / Two Homelands 43: 61-75.

Marotta, Vince P. (2010). The Cosmopolitan Stranger. Questioning Cosmopolitanism (eds. Stan Van Hooft, Wim Vandekerckhove. Netherlands: Springer: 105-120.

McCormack, Donna, Salmenniemi, Suvi (2016). The Biopolitics of Precarity and the Self. European Journal of Cultural Studies 19/1, 3-15.

Melossi, Dario (2003). 'In a Peaceful Life': Migration and the Crime of Modernity in Europe/Italy. Punishment and Society 4, 371-397.

Mezzadra, Sandro, Neilson, Brett (2013). Border as Method, or the Multiplication of Labor. Durnham, London: Duke University Press.

Mignolo, Walter D., Tlostanova, Madina V. (2006). Theorizing from the Borders: Shifting to Geo- and Body-Politics of Knowledge. European Journal of Social Theory 9/2, 205-221.

Mihelj, Sabina (2004). Negotiating European Identity at the Periphery: Media Coverage of Bosnian Refugees and 'Illegal Migration'. European Culture and the Media (eds. Ib Bondebjerg, Peter Golding). Bristol: Intellect Books, 165-189.

Nail, Thomas (2016). The Figure of the Migrant. Stanford: Stanford University Press.

Newman, Dennis (2006). Border and Bordering: Towards an Interdisciplinary Dialogue. European Journal of Social Theory 9/2, 171-86.

Nicolson, Michelle, Andreotti de Oliviera, Vanessa, Mafi, Boby Fortune (2016). The Unstated Politics of Stranger Making in Europe: A Brutal Kindness. European Journal of Cultural Studies 19/4, 335-351.

Nuhoğlu Soysal, Yasemin (1994). Limits of Citizenship: Migrants and Postnational Membership in Europe. Chicago, London: The University of Chicago Press.

Pajnik, Mojca (2016). 'Wasted Precariat': Migrant Work in European societies. Progress in Development Studies 16/2, DOI 10.1177/1464993415623130.

Pavlakovich Kochi, Vera, Morehouse, Barbara, Wastl Walter, Doris (2004). Challenged Borderlands: Transcending Political and Cultural Boundaries. Aldershot: Ashgate.

Petrović, Tanja, (2009). Dolga pot domov: Reprezentacije zahodnega Balkana v političnem in medijskem diskurzu. Ljubljana: Mirovni inštitut.

Robinson, William I. (2009). Saskia Sassen and the Sociology of Globalization: A Critical Appraisal, http://www.soc.ucsb.edu/faculty/robinson/Assets/pdf/Saskia\%20Sassen. pdf. (20. 2. 2017).

Sassen, Saskia (2014). Expulsions: Brutality and Complexity in the Global Economy. The Belknap Press of Harvard University Press.

Schippers, Thomas (2003). Sameness and Otherness: A View from France, Zuwanderung und Integration (eds. Christoph Köck, Alois Moosmüler). München: Waxmann, 42-50. 
Squires, Judith, (2002). Terms of Inclusion: Citizenship and the Shaping of Ethnonational Identities. Ethnonational Identities (eds. Steven Fenton, Stephen May). London: Palgrave, 227-251.

Štiks, Igor (2010). A 'Laboratory of Citizenship': Shifting Conceptions of Citizenship in Yugoslavia and its Successor States«, CITSEE Working Papers, http://www.law.ed.ac. uk/file_download/series/179_alaboratoryofcitizenshipshiftingconceptionsofcitizenshipinyugoslaviaanditssucces.pdf. (20. 2. 2017).

Todorova, Maria (2001). Imaginarij Balkana. Ljubljana: ICK.

Velikonja, Mitja (2005). Euroza - Kritika novega eurocentrizma. Ljubljana: Mirovni inštitut. Vidmar Horvat, Ksenija (2009). Zemljevidi vmesnosti: Evropska kultura im identiteta po koncu hladne vojne. Ljubljana: Sophia.

Walters, William (2006). Border / Control. European Journal of Social Theory 9/2: 187-203. 


\section{POVZETEK}

\section{BALKANSKA POT IN VARUHI EVROPE: BEGUNSKA KRIZA NA MEJAH SLOVENIJE}

\section{Ksenija VIDMAR HORVAT}

Članek obravnava javne odzive na begunsko krizo jeseni 2015. Analiza je vstavljena v kontekst teorij o globalizaciji in mejah. Glavnina sodobnih kritičnih razprav poudarja vlogo visoko tehnološko razvitih režimov meja. Pogosto se zdi, da tehnološki napredek meje potiska v vlogo avtonomnega akterja, ki deluje onkraj časa in prostora konkretnih ljudi. Nasprotno pa je begunska kriza poudarila drugačno resničnost meje in jo pahnila »nazaj« v zgodovino. Ta povratek je najočitnejši v izrazu geografija »migracijskih poti« v Evropo. Na Mediteranu t. i. »Mediteranska pot« oživlja zgodovino (post)kolonialnega nasilja; na jugovzhodu »Balkanska pot«s presečiščem na ozemljih postsocialističnih držav obnavlja pripoved o hladni vojni.

Članek vznik teh zgodovin obravnava v luči »post-schengenskega« imaginarija, ki določa predstave o »Balkanski poti« v Sloveniji. Jeseni 2015 je Slovenija samoiniciativno prevzela vlogo varuha Evrope. Kot pokaže analiza, je bila ta vloga prefiltrirana skozi spomine na 20. stoletje, še zlasti domnevno travmatično povezanost s socialističnim vzhodnim blokom. Ta samopodoba se vpenja $\mathrm{v}$ trenutno neoliberalno stanje prekarnosti eksistencialnih pogojev, ki v podobi migranta najde posebej priročno tarčo za izražanje frustracij in strahov o usodi v postsocialni državi. Temeljna teza je, da je kriza socialne države povzročila kontradiktorno uveljavljanje privilegija državljanstva: sprostitev primeža meje kot dela globalne neoliberalne politike je odprla pot za strah pred drugim, hkrati pa povsem zakrila lastno udeležbo v »zločinih" meje in profitabilnosti migracij.

Prispevek s konkretno analizo medijskega diskurza poudarja pomen zgodovinske obravnave javnih predstav o politični skupnosti, mejah in solidarnosti ter lokaliziranih analiz javnih idej o pripadanju, ki jih oblikujejo regionalne zgodovine. 